\title{
Nose-Rings and Transmission of Helminth Parasites in Outdoor Pigs
}

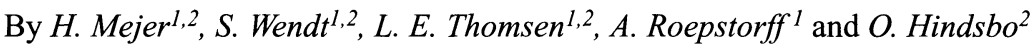

1Danish Centre for Experimental Parasitology, The Royal Veterinary and Agricultural University, Frederiksberg, and ${ }^{2}$ Department of Population Biology, Zoological Institute, University of Copenhagen, Denmark.

\begin{abstract}
Mejer H, Wendt S, Thomsen LE, Roepstorff A, Hindsbo O: Nose-rings and transmission of helminth parasites in outdoor pigs. Acta vet. scand. 2000, 41, 153-165. Five growing pigs experimentally infected with low doses of Oesophagostomum dentatum, Ascaris suum, and Trichuris suis were turned out with 5 helminth-naïve pigs on each of 3 pastures in June 1996 (Group 1). On one pasture all pigs received nose-rings. After slaughter of Group 1 in October, pasture infectivity was monitored using helminth-naïve, unringed tracer pigs. In 1997, helminth-naïve young pigs were turned out on the contaminated pastures in May (Group 2) and again in August (Group 3). Again all pigs on one pasture received nose-rings. All pigs and pastures were followed parasitologically and reduction in grass cover was monitored. Based on the acquisition of infection by the naïve pigs in Group 1, the estimated minimal embryonation times for eggs deposited on pasture were 23-25 days for $O$. dentatum, 5-6 weeks for A. suum and 9-10 weeks for T. suis. Results from tracer pigs and grass/soil samples indicated that pasture infectivity was light both years. Free-living stages of $O$. dentatum did not survive the winter. The nose-rings reduced rooting considerably, resulting in three-fold more grass cover on the nose-ring pasture compared to the control pastures by the end of the experiment. Nevertheless, the nose-rings did not significantly influence parasite transmission.
\end{abstract}

Ascaris suum; Trichuris suis; Oesophagostomum dentatum; transmission.

\section{Introduction}

In recent years different outdoor pig production systems have become more numerous. Compared to the modern indoor systems, the outdoor environment provides more favourable conditions for development, survival, and transmission of infective parasite stages. Keeping pigs outdoors may therefore increase both the number of parasite species and their prevalence in the pig population (reviewed by Nansen \& Roepstorff 1999), thus emphasizing the need for more knowledge on the epidemiology of parasite infections in order to develop efficient control strategies.

One of the most common pig helminths in outdoor herds in Denmark is Oesophagostomum spp. (Nansen \& Roepstorff 1999) which is transmitted as free-living larvae that may develop to infectivity within a short time but generally do not survive for long under Danish outdoor conditions (Kraglund 1999, Larsen personal communication). This helminth may be controlled either by pasture rotation combined with anthelmintic treatment (Rose \& Small 1983), or by predacious microfungi that attack the free-living larvae (Nansen et al. 1996). However, these principles may not target parasites such as Ascaris suum and Trichuris suis as efficiently, because they are transmitted by eggs which, although slow embryonating (Larsen \& Roepstorff 1999) and prone to high mortality 
rates (Kraglund 1999), may remain infective in the soil for years (Müller 1952/53, Burden et al. 1987). It is therefore necessary to find additional measures that may help control a wider spectrum of parasites, especially when preventive medication is not permitted, e.g. in organic farming systems. Nose-rings are commonly used to reduce damage to the pasture vegetation by suppressing the normal rooting behaviour of the pigs (Horrell et al. 1996). Nose-ringing pigs has therefore been suggested as an alternative way to reduce the uptake of infective parasite eggs and larvae from the soil (Larsen \& Roepstorff 1999).

The aim of the present study was to investigate if nose-rings could influence the transmission of helminths in outdoor pigs. The experiment was part of a larger study of parasite transmission, also including stocking rate (Thomsen et al. unpublished) and different aspects of pig behaviour (Wendt et al. unpublished). The overall design incorporated 2 control groups which are both included here for comparison with one group of nose-ringed pigs.

\section{Materials and methods}

\section{Experimental animals and feeding}

All pigs (females/castrated males) were crossbreeds of Danish Landrace $\times$ Yorkshire $\times$ Duroc purchased from an indoor herd that had previously not harboured helminth infections. In order to stimulate grazing and rooting, the pigs were given only $80 \%$ of the feed ration normally given to indoor fatteners. Rations were adjusted weekly.

\section{Parasite isolates}

The parasite strains and the cultures for development of infective eggs/larvae were identical to those previously described by Roepstorff \& Murrell (1997ab), except that the A. suum eggs were embryonated in vermiculite at room temperature according to Burden \& Hammet (1976).

\section{Experimental Design}

Group 1: In April 1996, fifteen pigs (Group 1A, mean body weight $(\mathrm{BW}) \pm \mathrm{SD}: 26 \pm 8 \mathrm{~kg}$ ) were inoculated twice by stomach tube with $25 \mathrm{~A}$. suum and 250 T. suis eggs and once with 1000 $O$. dentatum L3-larvae. Two months later these infected pigs (seeder pigs) were divided into 3 groups according to weight (mean BW: $60 \pm 12$ $\mathrm{kg}$ ), sex, litter, and egg-production by each parasite, and were turned out together with 5 helminth-naïve pigs (Group 1B, mean BW: $61 \pm 6$ $\mathrm{kg}$ ). On one of the pastures all 10 pigs received a nose- ring (Nose-ring), while the pigs on the other 2 pastures (Controls 1 and 2) did not receive a nose-ring. The pigs were weighed and samples of blood and faeces were collected every fortnight until necropsy approximately 16 weeks post turn-out (p.t.o.).

Tracer: From a group of helminth-naïve pigs that had adapted to outdoor conditions for 2 weeks on an assumed helminth-free pasture, 10 pigs (mean BW: $31 \pm 3 \mathrm{~kg}$ ) were transferred to each experimental pasture for 7 days in October 1996, whereafter they were moved back to their former pasture. The purpose of these Tracer pigs was to estimate the uptake of infective parasite stages from the pastures and none of the pigs were therefore ringed. Five pigs from each pasture (Tracer A) were slaughtered 16-17 days p.t.o. on the experimental pastures for recovery of $O$. dentatum and A. suum (infections 10-17 days old). The last $3 \times 5$ pigs (Tracer B) were slaughtered 35-36 days p.t.o. to recover all 3 parasite species (infections 29-36 days old). Samples (blood, faeces, weight) were collected before turn-out and at the first slaughter for Tracer A and B, and at the second slaughter for Tracer B.

Group 2: In May 1997, 3×10 helminth-naïve pigs (mean BW: $26 \pm 2 \mathrm{~kg}$ ) were turned out for 12 weeks. The pigs in Nose-ring received noserings, and sampling (blood, faeces, weight) was done every 4 weeks. As no $O$. dentatum egg ex- 
cretion could be detected by the end of June, all pigs were inoculated by stomach tube with 3000 O. dentatum L3-larvae to recontaminate the pastures.

Group 3: In August 1997 a new set of 3x10 helminth-naïve pigs (mean BW: $19 \pm 2 \mathrm{~kg}$ ) were turned out for 12 weeks. The pigs in Nose-ring received nose-rings and all pigs were sampled as described for Group 2.

\section{Experimental pastures}

The 3 pastures were all $2400 \mathrm{~m}^{2}$ and had never previously been used for pigs. At turn-out of Group 1 the vegetation was cut to a height of approximately $10-15 \mathrm{~cm}$ and consisted mostly of the grasses Bromus sp., Dáctylis sp., and Poa trivialis. The pigs had free access to water, an insulated house, and a wallowing area on each pasture. Due to the area available, 2 of the pastures (Nose-ring and Control 2) were elongate sharing a slight rise $(1.5 \mathrm{~m})$ in the terrain in the northern end, while one pasture (Control 1) was more square. A corner of the Control 2 pasture had some hours of shade in the afternoon.

\section{Grass cover}

An imaginary $5 \times 5 \mathrm{~m}$ grid was placed over the pastures. At each grid intersection an area (270 $\mathrm{cm}^{2}$ ) of the pasture was classified according to 5 categories, corresponding to an approximate grass cover of either $0,25,50,75$ or $100 \%$ (= grass cover values (v)) and a "grass cover index" was calculated for each pasture as:

Grass cover $=\frac{\sum \mathrm{n}_{\mathrm{i}} \times \mathrm{v}}{\sum \mathrm{n}_{\mathrm{i}}}$

where $n_{i}=$ number of intersections with a given grass cover value, and $\sum n_{i}=$ total number of classified intersections. The grass cover was estimated every 2 weeks for Group 1, before and after turn-out for the Tracer pigs, and every 4 weeks for Groups 2 and 3.

\section{Soil and grass samples}

Sub-samples of grass and soil were at each sampling collected close to the grid intersections and pooled to 1 grass or soil sample for each of the 3 pastures. The grass was cut directly above the ground and the soil taken from the top 2-3 cm using a small soil drill. $O$. dentatum third stage larvae were isolated from the soil (only in 1996) by a soil-Baermann technique described by Grønvold (1984), and from grass by an agar-gel technique according to the method of Jørgensen (1975). A. suum and T. suis eggs were extracted from the soil using a flotation method (Larsen \& Roepstorff 1999).

\section{Climate}

The air temperature was registered continuously and the rainfall measured daily approximately $800 \mathrm{~m}$ from the experimental area by The Department of Agricultural Sciences, Laboratory for Agrohydrology and Bioclimatology, The Royal Veterinary and Agricultural University.

\section{Parasitological techniques}

Faecal egg counts were determined using a concentration McMaster technique with a lower detection limit of 20 eggs per g faeces (epg) (Roepstorff \& Nansen 1998).

Blood sera were tested for antibodies against $A$. suum L2/L3 excretory-secretory products using an indirect ELISA method as described by Jungersen et al. (1999).

The pigs were fasted on the day of necropsy. They were euthanised either by a captive bolt pistol or a strong electrical current and bled, whereupon the liver and intestines were removed. The small intestine was emptied, opened, and pulled between 2 sticks twice in order to scrape off the mucus. The intestinal wall was then rinsed in $37^{\circ} \mathrm{C} 0.9 \%$ sodium chloride solution (saline), and the washings combined with the intestinal contents and mucus. Large $A$. 


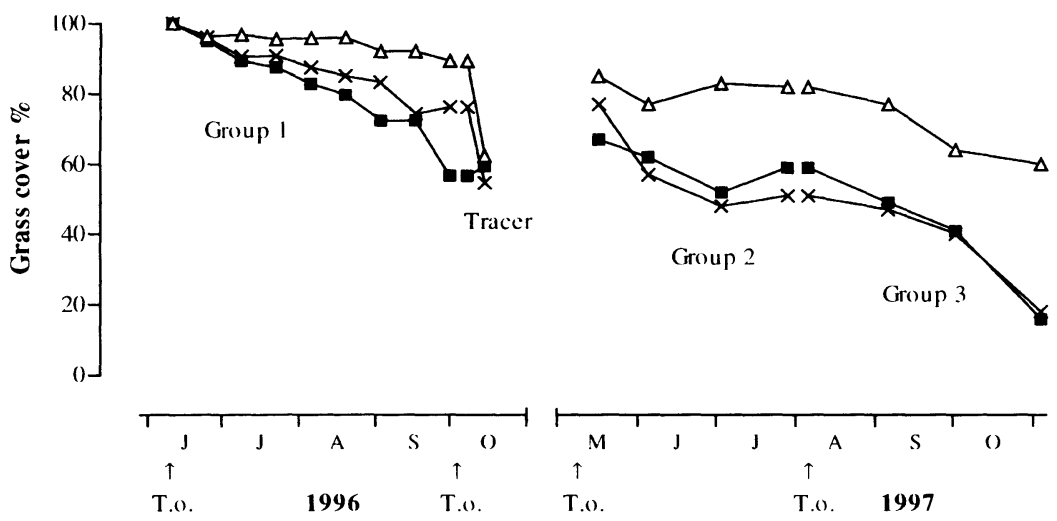

Figure 1. Grass cover on three pastures $\left(2400 \mathrm{~m}^{2}\right)$ due to the activity of different groups of pigs. Signature: Nose-ring $(\triangle)$, Control $1(\square)$, and Control $2(\times)$. On the Nose-ring pasture all pigs except Tracers were ringed at turn-out (T.o.) $(n=10$, except Control 1 in Group $2(n=9))$.

suum were collected, and 50\% (except Tracer: $100 \%$ ) of the intestinal contents was embedded in agar for isolation of smaller worms as described by Slotved et al. (1997). The large intestine was opened, emptied, and rinsed several times in saline. The contents and washings were thoroughly mixed and diluted with saline to a total volume of 101 , after which sub-samples of $10 \%$ (except Tracer: $100 \%$ ) and $20 \%$ were used for isolation of $O$. dentatum and $T$. suis, respectively. $O$. dentatum was isolated using the agargel method described by Slotved et al. (1996). The $T$. suis sub-samples were sieved as described by Roepstorff \& Murrell (1997b). The livers were examined for superficial white spots.

\section{Statistical analysis}

Statistical analysis was done using the MIXED procedures of the SAS software package, release 6.12 , with a $5 \%$ level of significance. ELISA-OD values and log transformed faecal egg counts were tested with a repeated measures analysis of variance, while log transformed worm burdens and liver white spots were analysed using a one-way analysis of variance. Both models investigated the effects and interactions of the independent variables pasture, time, and sex, eliminating them stepwise if nonsignificant, and included a least squares means analysis for specific differences between the 3 pastures. Data resulting primarily from experimental infections were not analysed statistically.

\section{Results}

Experimental animals

The pigs did not show clinical signs of helminth infections, but in Tracers, Group 1, and Group 2 a few animals were treated with antibiotics against arthritis. No evidence was found that either treatment or infection influenced the helminth status of the pigs. One pig in Control 1 of Group 2 died of unknown causes shortly after turn-out. Within the different groups the average weight gain was the same for all 3 pastures. In 1997, a total of 6 pigs lost their nose-rings in Groups 2 and 3. When possible the rings were 

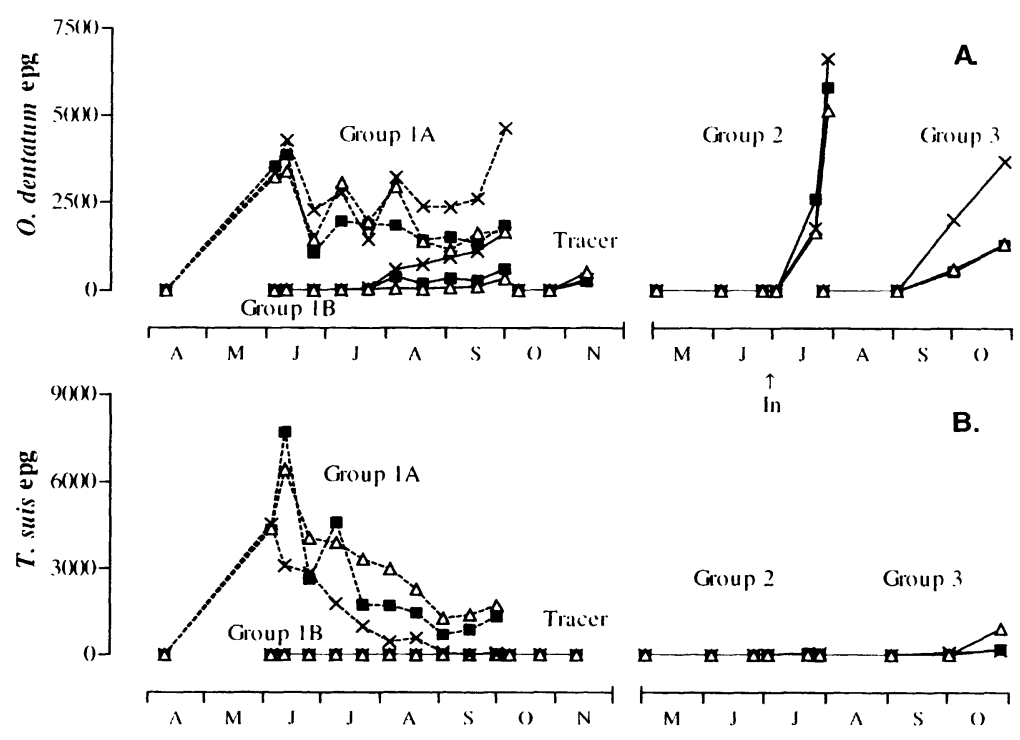

A.

B.
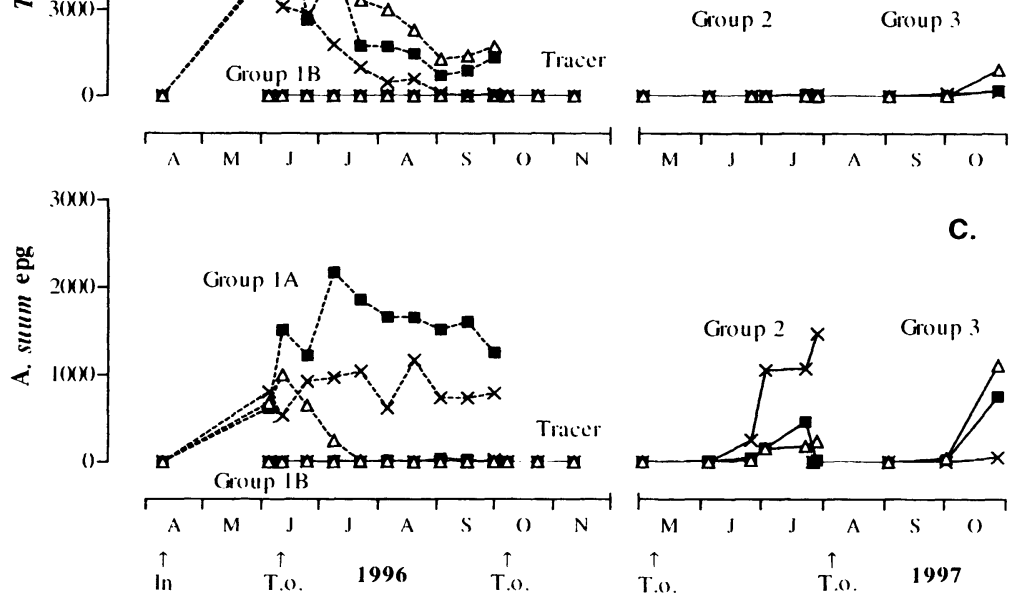

c.

Figure 2. Faecal egg counts (epg, arithmetic mean) of O.dentatum (A), T. suis (B), and A. suum (C) in flocks of ringed ( $\triangle$ Nose-ring) and unringed pigs ( $\square$ Control 1, $\times$ Control 2) on different pastures. Group $1 \mathrm{~A}(\mathrm{n}=5$, dotted lines) was inoculated (In) with 1000 O. dentatum L3-larvae, $2 \times 250$ T. suis eggs, and $2 \times 25$ A. suum eggs before turn-out (T.o.) together with helminth-naïve pigs, Group 1B $(n=5$, solid lines). Group $2(n=10 / n=9)$ and Group $3(n=10 / n=9)$ were helminth-naïve at turn-out, but the Group 2 pigs were later inoculated (In) with 3000 O. dentatum L3-larvae. Helminth-naïve Tracer pigs were not ringed (samplings 1 and 2: $\mathrm{n}=10$, sampling 3: $\mathrm{n}=5$ ).

replaced, but 3 pigs in Group 2 were without a ring the last 2 weeks before slaughter. In Group 3, 2 pigs were left without a ring for 4 weeks and 1 pig for 6 weeks. Only the results for the last pig have been excluded from the calculations due to a change (compared with the ringed pigs) towards normal rooting behaviour.

\section{Grass cover}

Applying nose-rings did not affect grazing but largely prevented normal rooting behaviour, except in areas with loose or very moist soil like in the house or the wallowing area. In areas with hard and dry soil the ringed pigs sometimes used the forefeet to scrape in the soil 
(pawing) while the snout was only used to gently palpate the ground. The effect of the ring was least pronounced in Group 1 (Fig. 1), where the pigs (especially in Control 2) were generally very inactive (Wendt et al. unpublished). When the pigs in Group 1 were slaughtered, the grass cover was estimated to be $89 \%$, $57 \%$, and $76 \%$ for Nose-ring, Control 1 , and Control 2, respectively. This difference was almost eliminated within 1 week by the very active Tracer pigs (Fig. 1). In 1997, the activity levels of the pigs on the 2 control pastures were more alike (Nørgaard-Nielsen, pers. comm.), and by the end of the experiment the grass cover had been reduced to less than $20 \%$ on both control pastures. For Nose-ring the cover was $60 \%$, and the reduction was primarily due to the $1 \mathrm{pig}$ in Group 3 that had lost the ring 6 weeks before slaughter.

\section{Soil and grass samples}

Few soil and grass samples were positive and these generally contained low numbers of eggs or larvae, and did therefore not give an indication of differences in the number of infective parasite stages on the pastures. In 1996, maxima of 93 O. dentatum L3-larvae $\mathrm{kg}^{-1}$ grass (dry weight) and 1.3 L3-larvae $\mathrm{g}^{-1}$ soil (dry weight) were recovered in single samples. During the first period of 1997 (Group 2) no larvae were found, whereas in the second period (Group 3) samples contained up to 1230 L3-larvae $\mathrm{kg}^{-1}$ grass. In 1996, up to 0.7 A. suum and 5.7 T. suis eggs $\mathrm{g}^{-1}$ soil (dry weight) were found, whereas no $A$. suum and only $1 T$. suis egg were recovered in 1997.

\section{Climate}

Compared with average values for the period of 1961 to 1991 (Rosenørn \& Lindhardt 1994), the mean daily temperature for each experimental month in 1996 was close to normal, whereas it was generally above average in 1997 . The to- tal rainfall $(176 \mathrm{~mm})$ during the experimental period of 1996 was only $52 \%$ of the average rainfall in the corresponding period of 19611991 (Rosenørn \& Lindhardt 1994), making it the driest summer and autumn for years. In contrast, the area received $12 \%$ more rain than normal during the experiment in 1997.

\section{Oesophagostomum dentatum}

At turn-out, $O$. dentatum egg excretion in the experimentally infected Group 1A was comparable on all 3 pastures, but at necropsy a substantial increase was registered in Control 2 (Fig. 2A). This corresponded to an average worm burden in Control 2 twice the inoculation dose and 4 times higher than in Nose-ring and Control 1 (Table 1). By subtracting a prepatency period of 17-19 days (Talvik et al. 1997) from the time of the first appearance of egg positive Group 1B pigs (42 days p.t.o.), it was deduced that some of the first eggs excreted by the Group 1A pigs developed to infective larvae within 23-25 days causing rapid reinfection. Statistical analysis showed an effect of pasture in Group 1B $(\mathrm{p}<0.001)$ due to a higher egg output on the Control 2 pasture that differed significantly from the other 2 pastures $(\mathrm{p}<0.01)$. No significant difference was found between Control 1 and Nose-ring. Analysis of the worm burdens also revealed an effect of pasture $(p=0.03)$, in that Control 2 pigs of Group 1B harboured more worms compared with Control 1 pigs $(\mathrm{p}=0.04)$ and Nose-ring pigs $(\mathrm{p}=0.01)$, while the latter 2 did not differ from each other. No statistical differences were found in the egg counts for Tracer B or the worm burdens for Tracer A and B (combined because they were comparable), although the latter were slightly higher in Control 2. Judged by the egg counts in Group 2, patent infections were not apparent until after the experimental infection, which resulted in almost identical high mean egg excretions and worm burdens for the pigs on all 3 pastures. For the naturally infected pigs in 
Table 1. Mean $\pm \mathrm{SD}$ (min-max) $O$. dentatum and T. suis worm burdens (mature+immature) in ringed (Nosering) and unringed (Control 1 and 2) pigs on pasture. Group 1(A and B) and Tracer were turned out in 1996, followed by Group 2 and subsequently Group 3 in 1997. The pigs in Group 1A were experimentally infected with 1000 O. dentatum L3-larvae and $2 \times 250$ T. suis eggs in order to start contamination of the pastures at turn-out. In Group 2, pigs were infected with 3000 O. dentatum L3-larvae, whereas the remaining infections were all due to natural exposure. The Tracer pigs were not nose-ringed.

\begin{tabular}{|c|c|c|c|c|c|c|}
\hline & \multicolumn{3}{|c|}{ O. dentatum } & \multicolumn{3}{|c|}{ T. suis } \\
\hline & Nosering & Control 1 & Control 2 & Nosering & Control 1 & Control 2 \\
\hline $\begin{array}{l}\text { Group 1A } \\
(n=5)\end{array}$ & $\begin{array}{l}578 \pm 185 \\
(370-770)\end{array}$ & $\begin{array}{l}462 \pm 491 \\
(50-1200)\end{array}$ & $\begin{array}{l}2152 \pm 1018 \\
(1020-3250)\end{array}$ & $\begin{array}{c}460 \pm 660 \\
(0-1455)\end{array}$ & $\begin{array}{c}404 \pm 835 \\
(0-1895)\end{array}$ & $\begin{array}{l}9 \pm 20 \\
(0-45)\end{array}$ \\
\hline $\begin{array}{l}\text { Group 1B } \\
(\mathrm{n}=5)\end{array}$ & $\begin{array}{c}114 \pm 126 \\
(0-290)\end{array}$ & $\begin{array}{c}160 \pm 182 \\
(25-470)\end{array}$ & $\begin{array}{c}698 \pm 567 \\
(300-1700)\end{array}$ & $\begin{array}{l}61 \pm 57 \\
(0-135)\end{array}$ & $\begin{array}{c}310 \pm 309 \\
(0-740)\end{array}$ & $\begin{array}{c}193 \pm 126 \\
(0-340)\end{array}$ \\
\hline $\begin{array}{l}\text { Tracer } \\
\left(\mathrm{n}=10 / 5^{*}\right)\end{array}$ & $\begin{array}{l}55 \pm 57 \\
(5-150)\end{array}$ & $\begin{array}{l}64 \pm 53 \\
(0-185)\end{array}$ & $\begin{array}{c}123 \pm 164 \\
(5-475)\end{array}$ & $\begin{array}{c}172 \pm 134 \\
(25-325)\end{array}$ & $\begin{array}{c}709 \pm 591 \\
(240-1645)\end{array}$ & $\begin{array}{l}407 \pm 787 \\
(35-1815)\end{array}$ \\
\hline $\begin{array}{l}\text { Group 2 } \\
\left(\mathrm{n}=10^{\square}\right)\end{array}$ & $\begin{array}{l}1982 \pm 677 \\
(240-2690)\end{array}$ & $\begin{array}{c}1798 \pm 985 \\
(10-3310)\end{array}$ & $\begin{array}{l}1820 \pm 704 \\
(530-2620)\end{array}$ & $\begin{array}{c}20 \pm 27 \\
(0-75)\end{array}$ & $\begin{array}{c}22 \pm 26 \\
(0-70)\end{array}$ & $\begin{array}{c}28 \pm 32 \\
(0-85)\end{array}$ \\
\hline $\begin{array}{l}\text { Group 3 } \\
\left(\mathrm{n}=10^{\otimes}\right)\end{array}$ & $\begin{array}{c}167 \pm 178 \\
(0-580)\end{array}$ & $\begin{array}{c}270 \pm 226 \\
(20-720)\end{array}$ & $\begin{array}{c}1043 \pm 779 \\
(40-2960)\end{array}$ & $\begin{array}{c}114 \pm 262 \\
(0-805)\end{array}$ & $\begin{array}{l}101 \pm 75 \\
(10-215)\end{array}$ & $\begin{array}{l}73 \pm 90 \\
(0-245)\end{array}$ \\
\hline
\end{tabular}

* O. dentatum: $\mathrm{n}=10$ and T. suis: $\mathrm{n}=5$

$\square$ Control $1 \mathrm{n}=9$

$\otimes$ Nose-ring $\mathrm{n}=9$

Group 3, egg production was higher for Control 2 compared with the other 2 pastures, but a significant difference was found only in relation to Nose-ring $(p<0.04)$. Significantly more worms were recovered from the Control 2 pigs in Group 3 than from the pigs on the other 2 pastures $(\mathrm{p}<0.03)$ (Table 1).

Trichuris suis

After turn-out the $T$. suis egg excretion in Group 1A decreased during the summer until a few weeks before slaughter when there was a slight increase in Control 1 and Nose- ring (Fig. 2B), corresponding with a higher worm recovery than in Control 2 (Table 1). In Groups 1B, 2 , and 3 only very few pigs had developed patent infections by the time of necropsy (weeks 16,12 and 12 p.t.o., respectively), and within each group the worm burdens did not differ statistically between pastures. With a prepatency period of approximately 6-7 weeks (Powers et al. 1960), some eggs excreted by the Group 1A pigs became infective to the Group 1B pigs within 9-10 weeks. All Tracer pigs were slaughtered before the end of the prepatency period. Their mean worm burdens were low and the smallest number of worms was found in Nosering and the highest in Control 1. Statistical analyses did not, however, reveal any significant differences. The same is also true for both Groups 2 and 3 where the level of infection in both cases was very low (less than in Group 1B), although slightly more worms were found in Group 3 than in Group 2 (see Table 1).

\section{Ascaris suum}

In the experimentally infected Group 1A, a few A. suum positive pigs contaminated the 2 control pastures more or less constantly throughout 


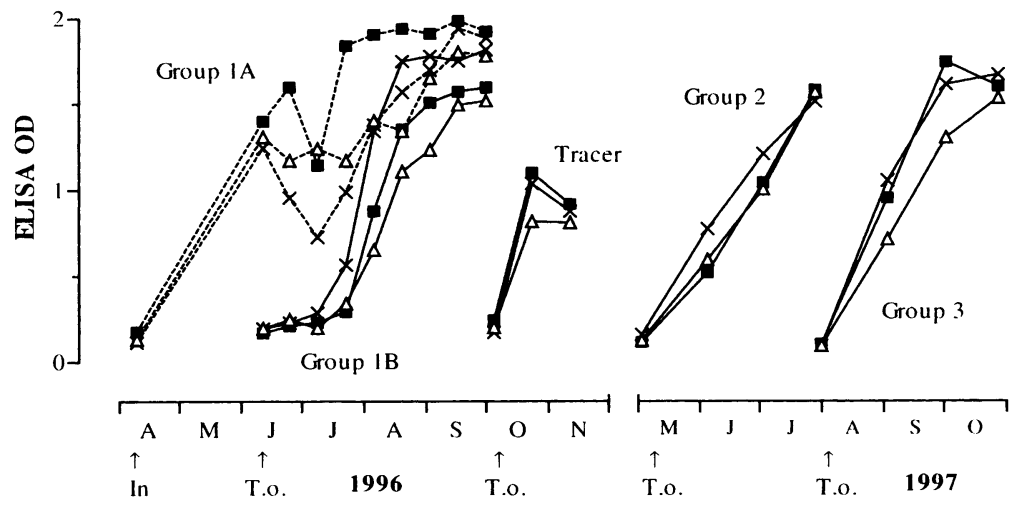

Figure 3. Ig response (ELISA OD-values, arithmetic mean) against $A$. suum L2/L3 excretory/secretory products in ringed ( $\triangle$ Nose-ring) and unringed pigs ( Control $1, \times$ Control 2$)$ on different pastures. The pigs in Group 1A ( $n=5$, dotted lines) were inoculated (In) with $2 \times 25$ A. suum eggs before turn-out (T.o.) together with helminth- naïve pigs, Group 1B $(n=5$, solid lines). Pigs in Group $2(n=10 / n=9)$ and Group $3(n=10 / n=9)$ were helminth-naïve at turn-out. On Nose-ring all pigs were ringed except for the helminth-naïve Tracer pigs (samplings 1 and $2: \mathrm{n}=10$, sampling $3: \mathrm{n}=5$ ).

the study period (most eggs being excreted by Control 1 pigs, Fig. 2C), while the few egg positive pigs in Nose-ring seemingly expelled their adult worms after approximately 6 weeks. Few of the naturally infected pigs in Group 1B excreted eggs, starting 12 weeks p.t.o. Allowing for a prepatency period of minimum 6-7 weeks (Roepstorff et al. 1997) the first eggs excreted by pigs in Group 1A reached infectivity on pasture within 5-6 weeks. None of the Tracer pigs developed patent $A$. suum infections. In contrast, low to very high egg counts were observed in a few pigs in Groups 2 and 3 (all pastures), but no significant differences between the pastures were found because of the large individual variation in worm counts.

After an initial surge in immune response in the experimentally infected Group 1A, the mean antibody levels fell and then rose again approximately 6-8 weeks p.t.o., reaching a plateau before necropsy (Fig. 3). The pigs in Group 1B began to seroconvert 6 weeks p.t.o., and the mean response then increased to almost the same level as in Group 1A. The combined serological data for Tracer A and B show that pigs on all pastures had seroconverted by day 16-17 p.t.o. Serum antibody responses increased linearly in both Groups 2 and 3, but only stabilized in Group 3 at the time of necropsy. The antibody levels at slaughter were, however, comparable to those in Groups 1A and 1B. Although Nose-ring in most groups seemed to have slightly lower ELISA OD-values, there was a large variation within all groups, and the only significant difference was found between Nose-ring and Control $2(\mathrm{p}<0.04)$ in Group 3. At necropsy worm burdens were overdispersed and on average only 1-12 A. suum (mainly adults + small immatures) were recovered from pigs on the different pastures in each group, the only exception being Tracer A where all pigs were infected and worm burdens generally were higher (especially in Control 1, Table 2). Statistical analysis did not show any significant differences within the groups. In Tracer A, 1-2 pigs from each pasture harboured a low number 
Table 2. Mean $\pm \mathrm{SD}$ (min-max) numbers of $A$. suum worms (mature+immature) and liver white spots in ringed (Nose-ring) and unringed (Control 1 and 2) pigs on pasture. Group 1(A and B) and Tracer (A and B) were turned out in 1996, followed by Group 2 and subsequently Group 3 in 1997. The pigs in Group 1A were experimentally infected with $2 \times 25 \mathrm{~A}$. suum eggs in order to start contamination of the pastures at turn-out. The remaining groups were all naturally infected. Tracer A and B were not nose-ringed.

\begin{tabular}{|c|c|c|c|c|c|c|}
\hline & \multicolumn{3}{|c|}{ A. suum } & \multicolumn{3}{|c|}{ White spots } \\
\hline & Nosering & Control 1 & Control 2 & Nosering & Control 1 & Control 2 \\
\hline $\begin{array}{l}\text { Group 1A } \\
(\mathrm{n}=5)\end{array}$ & $\begin{array}{l}2 \pm 2 \\
(0-6)\end{array}$ & $\begin{array}{l}10 \pm 9 \\
(1-19)\end{array}$ & $\begin{array}{c}4 \pm 6 \\
(0-15)\end{array}$ & $\begin{array}{c}11 \pm 14 \\
(0-35)\end{array}$ & $\begin{array}{c}9 \pm 3 \\
(5-13)\end{array}$ & $\begin{array}{l}13 \pm 8 \\
(6-26)\end{array}$ \\
\hline $\begin{array}{l}\text { Group 1B } \\
(\mathrm{n}=5)\end{array}$ & $\begin{array}{l}1 \pm 3 \\
(0-7)\end{array}$ & $\begin{array}{l}2 \pm 2 \\
(0-4)\end{array}$ & $\begin{array}{l}1 \pm 1 \\
(0-3)\end{array}$ & $\begin{array}{l}16 \pm 9 \\
(7-28)\end{array}$ & $\begin{array}{c}9 \pm 5 \\
(3-16)\end{array}$ & $\begin{array}{l}28 \pm 11 \\
(20-47)\end{array}$ \\
\hline $\begin{array}{l}\text { Tracer A } \\
(\mathrm{n}=5)\end{array}$ & $\begin{array}{l}50 \pm 62 \\
(2-156)\end{array}$ & $\begin{array}{c}257 \pm 183 \\
(3-515)\end{array}$ & $\begin{array}{c}63 \pm 106 \\
(3-251)\end{array}$ & $\begin{array}{l}54 \pm 29 \\
(23-86)\end{array}$ & $\begin{array}{l}217 \pm 101 \\
(130-353)\end{array}$ & $\begin{array}{l}38 \pm 18 \\
(19-61)\end{array}$ \\
\hline $\begin{array}{l}\text { Tracer B } \\
(\mathrm{n}=5)\end{array}$ & $\begin{array}{c}3 \pm 4 \\
(0-10)\end{array}$ & $\begin{array}{c}10 \pm 13 \\
(0-27)\end{array}$ & $\begin{array}{c}2 \pm 4 \\
(0-10)\end{array}$ & $\begin{array}{c}28 \pm 21 \\
(8-62)\end{array}$ & $\begin{array}{c}149 \pm 153 \\
(15-406)\end{array}$ & $\begin{array}{c}59 \pm 40 \\
(11-121)\end{array}$ \\
\hline $\begin{array}{l}\text { Group 2 } \\
\left(\mathrm{n}=10^{\square}\right)\end{array}$ & $\begin{array}{c}5 \pm 5 \\
(0-16)\end{array}$ & $\begin{array}{c}4 \pm 7 \\
(0-20)\end{array}$ & $\begin{array}{c}12 \pm 17 \\
(0-50)\end{array}$ & $\begin{array}{c}40 \pm 31 \\
(10-106)\end{array}$ & $\begin{array}{l}44 \pm 18 \\
(21-69)\end{array}$ & $\begin{array}{c}30 \pm 25 \\
(8-83)\end{array}$ \\
\hline $\begin{array}{l}\text { Group 3 } \\
\left(\mathrm{n}=10^{\otimes}\right)\end{array}$ & $\begin{array}{c}5 \pm 6 \\
(0-17)\end{array}$ & $\begin{array}{c}3 \pm 5 \\
(0-15)\end{array}$ & $\begin{array}{c}3 \pm 4 \\
(0-12)\end{array}$ & $\begin{array}{c}22 \pm 17 \\
(6-56)\end{array}$ & $\begin{array}{c}40 \pm 24 \\
(8-93)\end{array}$ & $\begin{array}{c}28 \pm 24 \\
(4-78)\end{array}$ \\
\hline
\end{tabular}

$\square$ Control $1 \mathrm{n}=9$

${ }^{\otimes}$ Nose-ring $n=9$

of immature $A$. suum (1-12 worms, 11-90 mm) that were clearly larger (i.e. older) than the worms that could have been picked up on the experimental pastures. As the ELISA results (Fig. 3) did not indicate that the uncontrolled infection caused an earlier seroconvertion (i.e. infection had been very light), the only measure taken was that worm burdens in Tracer A were adjusted by subtracting the larger worms before analysis.

Analysis of the liver white spots (Table 2) showed few differences: the pigs in Control 1 had significantly fewer lesions than the Control 2 pigs in Group $1 \mathrm{~B}(\mathrm{p}=0.02)$, but significantly more than Nose-ring $(p=0.005)$ and Control 2 $(\mathrm{p}<0.002)$ in Tracer A.

\section{Discussion}

The results indicate that, although nose-rings did reduce the rooting behaviour of the pigs considerably, the level of parasite transmission was not affected compared to unringed control pigs. This suggests that parasite transmission on pasture may be influenced more by pasture features (unidentified in this experiment) than the change in behaviour caused by the nosering.

Allowing for the respective prepatency periods (Powers et al.1960, Roepstorff et al. 1997, Talvik et al. 1997), the first $T$. suis eggs, $A$. suum eggs and $O$. dentatum larvae became infective to the Group 1B pigs within 9-10 weeks, 5-6 weeks, and 23-25 days, respectively, after the start of pasture contamination by Group 1A 
pigs. Short embryonation times on Danish pastures such as these for $O$. dentatum and $A$. suum correspond to previous reports (Roepstorff \& Murrell 1997ab, Larsen \& Roepstorff 1999). For T. suis it has been described that, although some eggs may become fully embryonated within one season, the large majority of eggs deposited during the summer do not become infective until the next season under field conditions (Burden \& Hammet 1979, Kraglund 1999, Larsen \& Roepstorff 1999). However, worm recoveries from helminth-naïve pigs in the present experiment confirm that patent $T$. suis infections may be achieved during the summer and autumn of the first year of grazing.

Outdoor plot studies have shown that during hot dry summers mortality rates may be very high for both $O$. dentatum larvae (Rose \& Small 1980, Kraglund 1999, M. Larsen pers. comm.) and A. suum and T. suis eggs (Larsen \& Roepstorff 1999, Kraglund 1999). This was irrespective of where the eggs were deposited, although high grass (Rose \& Small 1981, Kraglund 1999) or burial in soil (Larsen \& Roepstorff 1999, M. Larsen pers. comm.) did provide some protection for the free-living parasite stages against harsh climatic conditions. Although not exceptionally warm, the summer of 1996 was very dry and this may explain why pasture infectivity and overall transmission levels were low, despite a considerable contamination with eggs from all 3 parasites by the seeder pigs. The winter climate also proved detrimental to the $O$. dentatum larvae as they did not survive to infect the pigs that were turned out the following summer. Our results are in accordance with those of Smith (1979), whereas others have shown that very low numbers of larvae may survive, allowing transmission, although severely reduced, to take place during the winter and early in the following summer (Roepstorff \& Murrell 1997a). Overall, this suggests that if infected free-range pigs are efficiently treated with anthelmintics during the winter, $O$. dentatum may be eliminated.

The soil and grass samples indicate that pasture infectivity was light in both years for all 3 parasites, but the results did not show if the levels of infectivity were different on the 3 pastures. This may in part be due to poor survival of the free-living stages combined with selective defaecation by the pigs, concentrating the faeces to certain areas of the pasture (Wendt et al. unpublished). Consequently, sampling from the grid intersections, which were evenly distributed over the entire pasture, may not have provided a good estimate of the bioavailability of eggs and larvae on the pastures. The worm burdens of the helminth-naïve Tracer pigs were probably a better means to determine the pasture infectivity.

In 1996, the $O$. dentatum infection level was higher in pigs on the Control 2 pasture than in the pigs on the other 2 pastures in Group 1B, and only the Group 1A pigs from the Control 2 pasture became noticeably reinfected. The higher transmission was further reflected by the slight, though not significant, difference in the Tracer worm burdens (Table 1). The conditions for development of infective $O$. dentatum larvae may therefore not have been identical on the 3 pastures. Pasture contamination in 1996 and 1997 were 2 separate events, and though similar numbers of eggs were excreted on all 3 pastures in 1997, worm recovery was again highest in pigs from the Control 2 pasture. Thus, it seems that the level of $O$. dentatum transmission was determined more by differences in pasture infectivity, due to differences in unidentified microclimatic conditions, than whether or not the pigs had a nose-ring. Why the conditions were different was not determined in our study, but perhaps the few hours of shade in a corner of the Control 2 pasture may have had a protective effect and thereby increased the development of eggs and larvae. Unless infection 
doses are extremely high, little immunity develops with time against $O$. dentatum (Christensen et al. 1995, Roepstorff et al. 1996). Immunity is therefore not expected to have influenced the infection levels.

Nose-rings did not significantly affect the transmission of $T$. suis in the course of the experiment. The pigs in Group 1B were presumably slaughtered before onset of protective immunity against $T$. suis (i.e. approximately 8 weeks after inoculation, L. Mansfield pers. comm.), and the worm burdens should therefore reflect the uptake of infective eggs. The population kinetics of $T$. suis infections in pigs is not known in detail, but it is possible that some type of dose-dependent regulation of the intestinal worm burden may also have been involved, as has been suggested for T. suis (Pedersen et al. unpublished) and also $O$. dentatum (Rose \& Small 1980). Judging from the soil samples and the Tracer pigs, however, it seems unlikely that pasture infectivity was sufficient to elicit a strong immune response or induce other worm population regulation mechanisms in the naturally infected pigs. The lack of egg excreting pigs in 1997 until slaughter of Group 3 further indicates very low transmission rates during the second summer. It may therefore be assumed that fewer infective eggs were available to the pigs in the second grazing season because of poor survival of eggs, though development of $T$. suis eggs may have continued during the second year as the Group 3 pigs generally harboured slightly more worms than the Group 2 pigs.

Infection with $A$. suum is characterized by strong acquired immunity, resulting in small overdispersed worm burdens that are more or less dose-independent (Roepstorff et al. 1997, Eriksen et al. 1992). Similarly, the numbers of white spots become dose-independent few weeks after a single infection (Roepstorff et al. 1997) and approximately 2 months of trickle exposure (Eriksen et al. 1992). It is therefore not surprising that the worm burdens and numbers of white spots were low and comparable within all the long-term exposed groups as well as the group of tracers that was slaughtered late after exposure. This makes it impossible to assess whether or not the nose-rings did reduce the transmission of $A$. suum. The ingestion of infective eggs was, however, substantial enough for the nose-ringed pigs to elicit a considerable antibody response against the migrating larvae. Lind et al. (1993) showed that the rate of seroconversion is dose-dependent, and a seasonal variation in seroconversion of tracer pigs has shown that it may reflect pasture infectivity (Roepstorff \& Murrell 1997b). The present results thus indicate that the faster response in the autumn group of 1997 compared to the summer group was due to a higher transmission rate of A. suum. Excretion of A. suum eggs from the seeder pigs (Group 1A) was considerably less on the Nose-ring pasture than on the 2 control pastures. This is probably the reason for the somewhat lower levels of serum antibody in all the subsequent pigs on this pasture with (Groups 1B, 2, and 3) or without nose-rings (Tracer).

The fact that the nose-rings did affect pig behaviour but apparently not parasite transmission suggests that, although rooting was reduced, the pigs still had sufficient contact with the pasture surface to allow transmission to occur successfully. This is in accordance with the behavioural observations of Wendt et al. (unpublished), who showed that grazing was not affected by nose-rings, and that the pigs compensated for their inability to root normally by rooting in the wallowing area more frequently than the pigs without nose-rings. Furthermore, it was shown that faeces and, consequently, eggs and larvae (Thomsen et al. unpublished) were unevenly distributed on the pasture, resulting in an uneven exposure distribution for individual pigs. Very few large scale experiments have previ- 
ously been carried out on pig helminth transmission, and the results from the present experiment provide novel information on the epidemiology of helminths in fatteners on pasture. The results do however not indicate that giving pigs nose-rings will provide a way of controlling helminth transmission as suggested by Larsen \& Roepstorff (1999). The overall transmission rates in the current study were low, and it is possible that nose-rings may have an effect under other circumstances. Further work is therefore needed before it can be finally concluded, whether or not nose-rings may have an effect on parasite transmission between freerange pigs.

\section{Acknowledgement}

The study was funded by the Danish Directorate for Development (grant 96.01.015.17) and the Danish National Research Foundation through the Danish Centre for Experimental Parasitology. We are grateful to Gudrun Ellendersen and Marlene Høg for valuable technical assistance and to Annette Ersbøll and Stig M. Thamsborg for help with the statistics. We also wish to thank Niels Midtgaard for coordinating the field work, just as Morten Hors, Nick Bonnichsen, Jørgen Olesen, Lars Staun, and Jørgen Nielsen are thanked for taking good care of the pigs. Svend Erik Jensen at the Department of Agricultural Sciences, Laboratory for Agrohydrology and Bioclimatology, The Royal Veterinary and Agricultural University, Copenhagen is gratefully acknowledged for providing the climate data.

\section{References}

Burden DJ, Hammet NC: A comparison of the infectivity of Trichuris suis ova embryonated by four different methods. Vet. Parasitol. 1976, 2, 307311.

Burden DJ, Hammet NC: The development and survival of Trichuris suis ova on pasture plots in the south of England. Res. Vet. Sci. 1979, 26, 66-70.

Burden DJ, Hammet NC, Brookes PA: Field observations on the longevity of Trichuris suis ova. Vet. Rec. 1987, 121, p. 43.

Christensen CM, Barnes EH, Nansen P, Roepstorff A, Slotved HC: Experimental Oesophagostomum dentatum infection in the pig: worm populations resulting from single infections with three doses of larvae. Int. J. Parasitol. 1995, 25, 1491-1498.

Eriksen L, Nansen P, Roepstorff A, Lind P, Nilsson O: Response to repeated inoculations with Ascaris suum eggs in pigs during the fattening period. I. Studies on worm population kinetics. Parasitol. Res. 1992, 78, 241-246.

Grønvold J: Isolation of infective Cooperia larvae from soil samples. Acta Vet. Scand.1984, 25, 139-142.

Horrell RI, A'Ness PJ, Edwards SA: The impact of nose-rings on the micro-actions of rooting in pigs. Proc. 30th Int. Cong. Int. Soc. Appl. Ethol. 1996, p. 101.

Jungersen G, Eriksen L, Roepstorff A, Lind P, Meeusen ENT, Rasmussen T, Nansen P: Experimental Ascaris suum infection in the pig: Protective memory response after three immunizations and effect of intestinal adult worm population. Parasite Immunol. 1999, 21, 619-630.

Jørgensen RJ: Isolation of infective Dictyocaulus larvae from herbage. Vet. Parasitol. 1975, 1, 6167.

Kraglund H-OR: Survival, development and dispersal of free-living stages of Ascaris suum, Oesophagostomum dentatum and Trichuris suis at pasture. Ph.D. Thesis, Royal Veterinary and Agricultural University, Copenhagen, 1999, pp.118.

Larsen MN, Roepstorff A: Seasonal variation in development and survival of Ascaris suum and Trichuris suis eggs on pastures. Parasitology 1999, 119, 209-220.

Lind P, Eriksen L, Nansen P, Nilsson O, Roepstorff A: Response to repeated inoculations with Ascaris suum eggs in pigs during the fattening period. II. Specific IgA, IgG, and IgM antibodies determined by enzyme-linked immunosorbent assay. Parasitol. Res. 1993, 79, 240-244.

Müller $G$ : Untersuchungen über die Lebensdauer von Askaridieneiern in Gartenerde. (Investigation of the survival of Ascaris eggs in garden soil). Zentralblatt für Bakteriologie, Parasitenkunden, Infektionskrankheiten und Hygiene 1952/53, 159, 377-379.

Nansen P, Larsen M, Roepstorff A, Grønvold J, Wolstrup J, Henriksen SA: Control of Oesophagostomum dentatum and Hyostrongylus rubidus in outdoor-reared pigs by daily feeding with the microfungus Duddingtonia flagrans. Parasitol. Res.1996, 82, 580-584.

Nansen P, Roepstorff A: Parasitic helminths of the pig: factors influencing transmission and infection levels. Int. J. Parasitol. 1999, 29, 877-891. 
Powers KG, Todd AC, McNutt SH: Experimental infections of swine with Trichuris suis. Am. J. Vet. Res. 1960, 21, 262-268.

Roepstorff A, Bjørn H, Nansen P, Barnes EH, Christensen CM: Experimental Oesophagostomum dentatum infections in the pig: worm populations resulting from trickle infections with three dose levels of larvae. Int. J. Parasitol. 1996, 26, 399408.

Roepstorff A, Eriksen L, Slotved HC, Nansen P: Experimental Ascaris suum infection in the pig: worm population kinetics following single inoculations with three doses of infective eggs. Parasitology $1997,115,443-452$.

Roepstorff A, Murrell KD: Transmission dynamics of helminth parasites of pigs on continuous pasture: Oesophagostomum dentatum and Hyostrongylus rubidus. Int. J. Parasitol. 1997a, 27, 553-562.

Roepstorff A, Murrell KD: Transmission dynamics of helminth parasites of pigs on continuous pasture: Ascaris suum and Trichuris suis. Int. J. Parasitol. 1997b, 27, 563- 572.

Roepstorff $A$, Nansen P: The epidemiology, diagnosis and control of helminth parasites of swine. A FAO Handbook, FAO, Rome, 1998.

Rose JH, Small AJ: Transmission of Oesophagostomum spp. among sows at pasture. Vet. Rec. 1980, 107, 223-225.

Rose JH, Small AJ: The relationship between pasture herbage and the development of the free-living stages of Oesophagostomum dentatum. J. Helminthol. 1981, 55, 109-113.

Rose JH, Small AJ: Observations on the effect of anthelmintic treatment on the transmission of Hyostrongylus rubidus and Oesophagostomum spp. among sows at pasture. J. Helminthol. 1983, 57, $1-8$.

Rosenørn $S$, Lindhardt $K$ : Dansk vejr i 100 år (Danish weather during 100 years). Lademann, Copenhagen, 1994, pp. 213.

Slotved HC, Barnes EH, Bjørn H, Christensen CM, Eriksen L, Roepstorff A, Nansen P: Recovery of Oesophagostomum dentatum from pigs by isolation of parasites migrating from large intestinal contents embedded in agar-gel. Vet. Parasitol. 1996, 63, 237-245.
Slotved HC, Barnes EH, Eriksen L, Roepstorff A, Nansen P, Bjørn H: Use of an agar-gel technique for large scale application to recover Ascaris suum larvae from intestinal contents of pigs. Acta Vet. Scand. 1997, 38, 207-212.

Smith HJ: Transmission of Oesophagostomum species in swine on pasture in the maritime provinces. Can. Vet. J. 1979, 20, 184-185.

Talvik H, Christensen CM, Joachim A, Roepstorff A, Bjørn $H$, Nansen P: Prepatent periods of different Oesophagostomum spp. isolates in experimentally infected pigs. Parasitol. Res. 1997, 83, 563568.

\section{Sammendrag}

Noeseringe og transmission af helminther $i$ udendørs grise.

Fem slagtesvin, som var eksperimentelt inficeret med lave doser af Oesophagostomum dentatum, Ascaris suum og Trichuris suis, blev sammen med 5 helminth-naive grise bundet ud på hver af 3 folde $\mathrm{i}$ juni 1996 (Gruppe 1). På én af markerne fik alle grise isat en næsering. Efter slagtning af grisene i Gruppe $1 \mathrm{i}$ oktober blev marksmitten undersøgt ved hjælp af helminth-naive tracergrise uden næse-ring. I $1997 \mathrm{blev}$ helminth-naive grise bundet ud på de kontaminerede marker i maj (Gruppe 2) og igen i august (Gruppe 3). På den ene mark fik alle grise ring $i$ næsen. Alle grise og marker blev fulgt parasitologisk, og nedslidningen af græsdækket blev registreret. Udfra den begyndende ægudskilllelse af de helminthnaive grise i Gruppe 1, blev det estimeret, at de første infektive parasitstadier blev udviklet på markerne $\mathrm{i}$ løbet af 23-25 dage for $O$. dentatum, 5-6 uger for $A$. suum og 9-10 uger for T. suis. Resultater fra tracergrisene og græs-/jordprøver indikerede, at marksmitten var lav begge år. De fritlevende stadier af $O$. dentatum overlevede ikke vinteren. Næseringene reducerede grisenes rodeadfærd væsentligt med det resultat, at græsdækket ved forsøgets afslutning var 3 gange større på næseringsmarken end på de 2 kontrolmarker. Alligevel påvirkede næseringene ikke parasittransmissionen signifikant.

(Received December 8, 1999; accepted February 4, 2000).

Reprints may be obtained from: H. Mejer, Danish Centre for Experimental Parasitology, The Royal Veterinary and Agricultural University, Ridebanevej 3, DK-1870 Frederiksberg C, Denmark. E-mail: hem@kvl.dk, tel: +45 352827 92, fax: +45352827 74. 